\title{
The role of first-year experience excursion in promoting social integration at university: Student teachers' views
}

\begin{tabular}{|c|c|}
\hline \multicolumn{2}{|c|}{$\begin{array}{l}\text { Authors: } \\
\text { Delia Arends }{ }^{1} \\
\text { Nadine F. Petersen }\end{array}$} \\
\hline \multicolumn{2}{|c|}{$\begin{array}{l}\text { Affiliations: } \\
{ }^{1} \text { Centre for Education Practice } \\
\text { Research, University of } \\
\text { Johannesburg, South Africa }\end{array}$} \\
\hline \multicolumn{2}{|c|}{$\begin{array}{l}{ }^{2} \text { Department of Childhood } \\
\text { Education, University of } \\
\text { Johannesburg, South Africa }\end{array}$} \\
\hline \multicolumn{2}{|c|}{$\begin{array}{l}\text { Corresponding author: } \\
\text { Delia Arends, } \\
\text { deliaa@uj.ac.za }\end{array}$} \\
\hline \multicolumn{2}{|c|}{$\begin{array}{l}\text { Dates: } \\
\text { Received: } 15 \text { May } 2017 \\
\text { Accepted: } 27 \text { June } 2018 \\
\text { Published: } 19 \text { Nov. } 2018\end{array}$} \\
\hline \multicolumn{2}{|c|}{$\begin{array}{l}\text { How to cite this article: } \\
\text { Arends, D. \& Petersen N.F., } \\
\text { 2018, 'The role of first-year } \\
\text { experience excursion in } \\
\text { promoting social integration } \\
\text { at university: Student } \\
\text { teachers' views', South } \\
\text { African Journal of Childhood } \\
\text { Education } 8(1) \text {, a543. https:// } \\
\text { doi.org/10.4102/sajce. } \\
\text { v8i1.543 }\end{array}$} \\
\hline \multicolumn{2}{|c|}{$\begin{array}{l}\text { Copyright: } \\
\text { (c) 2018. The Authors. } \\
\text { Licensee: AOSIS. This } \\
\text { is licensed under the } \\
\text { Creative Commons } \\
\text { Attribution License. }\end{array}$} \\
\hline \multicolumn{2}{|l|}{ Read online: } \\
\hline 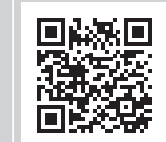 & $\begin{array}{l}\text { Scan this QR } \\
\text { code with your } \\
\text { smart phone or } \\
\text { mobile device } \\
\text { to read online. }\end{array}$ \\
\hline
\end{tabular}

Background: The Faculty of Education at the University of Johannesburg, like many other universities worldwide, has a strong focus on first-year experience programmes to promote student academic and social enculturation.

Aim: In this article, we report on students' views of the role of an education excursion as cohesive device. We were particularly interested in how students establish social relationships with peers, and the values they attribute to these connections over time for their incorporation into university.

Setting: The education excursion consists of a specially designed curriculum in the two day programme, off campus, as an extension of the initial first year seminar.

Methods: Using methods associated with longitudinal studies, we collected data via a biographical survey and questionnaire for first years, followed by dyadic interviews with a purposive sample of students 30 months later. Qualitative content analysis led to several findings.

Results: First-year data reveal that students face many challenges to their integration and that the excursion helps them traverse their individual racial, cultural and religious and language differences. Third years communicate the lasting effects of the excursion on their social and academic integration into university.

Conclusion: The authors conclude that the excursion has long-term value for students' social integration into the university environment and for bridging the gap between the university lecturers and the students.

\section{Introduction}

This article reports on student views of how an education excursion, as a small-scale living and learning experience (Moja 2010), promotes social integration in a customised first-year experience (FYE) programme in the Faculty of Education at the University of Johannesburg. Small-scale living and learning experiences emerge from an evolving movement to improve undergraduate education (Smith 2001) and emphasise a focused approach to promoting student connections at university (Palmer 1998). Most of the first-year student teachers are first-generation university learners and research (Fan, Buckley \& Litchfield 2012; Leibowitz, van der Merwe \& van Schalkwyk 2012) shows they have a need for a well-directed intervention to accelerate their process of enculturation into university life, socially, and in terms of the curriculum. In response to this need, the faculty designed and implemented a new programme of learning in an excursion for first-year students (Petersen, de Beer \& Dunbar-Krige 2011). As intervention, the excursion aims to address key social and pedagogical elements of professional learning in becoming a teacher. In addition, the excursion intends to help students bridge the often-difficult transition from high school to university and to increase the creation of social networks as the basis of learning communities over the whole degree programme (Du Preez, Steenkamp \& Baard 2013; Hunter 2006).

In some US-based research, there are advocates for FYE seminars or programmes for promoting student retention (Jenkins-Guarnieri et al. 2015) while others such as Miller and Lesik (2014) question its long-term efficacy. In South Africa, FYE seminars are increasingly seen as a way of promoting student retention and addressing first-generation students' need to adjust to higher education. The low graduation output of South African universities has long been a cause for concern and is well documented (Van Zyl 2012). National cohort studies (CHE 2013; Letseka \& Maile 2008; Scott, Yeld \& Henry 2007) paint a gloomy picture. Higher education participation 
rates remain low, in comparison with those of other countries (Berkovitz \& O'Quinn 2006; Moodley \& Singh 2015; Quinn 2013). In 2007 already, Scott et al. reported that only $30 \%$ of South African students enrolling in a 3-year degree programme eventually graduate; this has not changed much over the last 10 years. From 2013, annual graduate reports by the Department of Higher Education and Training show that up to $47.9 \%$ of students drop out of universities in South Africa while van $\mathrm{Zyl}$ (2012) argues that the first-year dropout rate is closer to $50 \%-60 \%$. Of the (limited numbers of) students who enter South African universities, less than 50\% of the students who enrol for diplomas or degrees graduate, and only one in three students of the intake into 3-year degrees in contact institutions graduate, even within 4 years. When factoring in race, the completion rates are even more shocking; Monama (2013) and Smith (2013) claim that only $5 \%$ of black students and mixed-race students graduate from university. A Council on Higher Education report (2013) indicates that white students on average have a $50 \%$ higher completion rate than non-white students. In a system that starts with an already low student intake, it is particularly demoralising when less than half of them graduate.

At the University of Johannesburg, figures for the 2001 cohort of one of its predecessor institutions, the Rand Afrikaans University, indicate that of the 3006 students who registered for a general Bachelor's degree (of 3 years), 33\% graduated in minimum time, rising to $59 \%$ by 2005 (after an additional 2 years). For the 2013 cohort (who graduated in 2015), the completion in minimum time is at $39.5 \%$ (Academic Development and Support Annual Report, 2015 University Teaching and Learning presentation 2017). The University of Johannesburg's (UJ) cohort studies over the period 2009 to 2013 shows a promising upwards trend, with approximately 4 out of 10 students completing their degrees in minimum time. In this respect, the UJ at $37.2 \%$ fares considerably better than the national sector average of $29 \%$. The UJ's 2015 and 2016 first-year dropout rates are still concerning at $18.6 \%$ and $16.7 \%$, respectively, with financial difficulties being high on the list of reasons why students do not return (see also Moodley \& Singh 2015). These figures are similar to research conducted by the Council on Higher Education (2010) on student dropout in three South African universities. In 2015 and 2016, the often violent \#fees must fall student protests was a stark reminder that South African first-year students are under immense financial pressure to pay for their initial degrees and graduate in minimum time (usually between 3 and 4 years depending on the qualification type). In addition, although there has been an increase in the number of nonwhite students completing their studies, the data still confirm substantial differences in graduation rates between various ethnic groups. In 2015, the UJ's first time entering student survey questionnaire showed that $63.8 \%$ of students were first-generation students. For the UJ, the situation is compounded by numerous other challenges: operating on several campuses, the large classes and struggle with addressing academic literacy of a body of students who have English as a third and sometimes fourth language.
Tinto $(1975,1987)$ stresses that the number and quality of interactions students experience within the institution directly influence their academic and cultural integration. In this respect, students' social experiences are important, as it is often cited as one of the major factors in their decision to remain at university (Mayo, Helms \& Codjoe 2004). Social support, such as a helpful peer group, has also been found to be a good predictor of student success (DeBerard, Spielmans \& Julka 2004:6). There is a slew of research over the last 30 years (Pace 1980; Kuh 2003) which operationalises the idea of social integration, with many universities implementing innovations to encourage student interaction (Zhao \& Kuh 2004). However, this list is not exhaustive, nor are innovations equally useful in all contexts for all students, and researchers admit that there is still much work to be done in this field. In this study, we examine the role of an educational field excursion in helping first-year pre-service teachers to establish social relationships with peers. We also look into the value they attach to these connections for their integration into university and if these relationships have persisted over time.

\section{Background to the study}

The excursion, which first started in 2007 (De Beer, Petersen \& Dunbar-Krige 2012), has evolved over the last 9 years to comprise an intervention in which students and academic staff, accompanied by peer tutors, live and learn together for 3 days outside of the formal university environment. The intervention is aimed at supporting first-year students in their transition into university by addressing the connections between their social, academic, and professional learning and building both social and curricular cohesion in the teacher education programme. In the systematically structured excursion curriculum, students work in groups in mostly games-based formats covering topics such as energy conservation and HIV and AIDS (Petersen et al. 2011), stereotyping, poverty and food security (Petersen 2014), leadership and pedagogies for teaching in schools with optimal diversity (De Beer \& Henning 2011). The excursion challenges students to face, head-on, the reality of becoming a teacher in a diverse and struggling society. The themes and activities of the excursion curriculum are integrated with particular modules in the teacher education curriculum, so that the lecturers can 'pick up' on discussions when students return to the formal university classroom. For the duration of the intervention, we deliberately group students outside of their spontaneous ethnic, gender and cultural peer grouping to form working entities that are optimally diverse. The students' tutors accompany the lecturers and help with facilitation of activities and student support (Govender 2014).

\section{Study of the literature}

First-year students are, in the words of Turner (1969), in a 'betwixt and between' (Turner 1969) liminal space when they leave high school to enter a very different institution. In their rite of passage (Van Gennep 1969), this liminal period on the threshold of university life and young adulthood may define 
their future in many ways. It is thus important that this period be recognised as an important transition from one 'cultural space' to another, during which students form new relationships, some of which can be social and learning relationships in an informally structured, small community of peers and others, where opportunities are created for them to live and learn more cohesively in a new educational space.

Research (Hunter 2006) on first years at university highlights the difficulties students face during this transition, which often leads to poor retention or dropout. In South Africa, the situation is especially bleak for black students, who have higher attrition rates than other race groups (CHE 2013; Murray 2014). Many black students can be classified as 'non-traditional students', or first-generation students, that is, students who come from backgrounds where there is a very weak or non-existent link with higher education or who are the first generation of students to enter higher education in their families. These first-generation students have not traditionally been catered for in higher education contexts and they may be more likely to experience a 'culture clash' - a clash between their school learning cultures and the dominant institutional culture as well as home and community culture (Cavote \& Kopera-Frye 2007:479). Van Zyl (2010:35) has been leading research in this area at the UJ and he uses Bourdieu's notions of 'cultural capital' and 'habitus' to argue that differences in cultural capital that students bring to their university education impacts directly on their success or failure. These include cultural resources such as previous education backgrounds, and familiarity with the cultural codes in the educational setting. Thus, students from families who have sufficient prior knowledge of the cultural codes of the academic environment are more likely to succeed than those from backgrounds that do not have the same storehouse of cultural codes to draw on.

Additionally, there is the problem of poor student outcomes. This is a 'complex and multilayered' concern and includes a number of influencing factors. For instance, Seligman and Gravett (2010) draw attention to students' problems with literacy and language, while Morrow (1994) points to students' lack of preparedness for how teaching and learning are organised, and the competence and qualifications of academic staff in meeting the learning needs of a diverse range of students.

One key issue, which has emerged in this debate, is that improving graduate output is tied to measures to address student enculturation into the academic environment and the effectiveness of the educational process in higher education. It is in this respect that the education excursion may serve as an opportunity for students to initiate and learn to build social networks, which we argue is the platform for the establishment of long-term groups that learn by being together. Here we are guided by the work of Braxton and McClendon (2001-2002) who contend that orientation programmes should develop multiple opportunities for first-year students to socially interact with their peers. The excursion is our way of assisting first years from diverse social and cultural backgrounds to begin to traverse the difficulties of the transitional year. It also exposes students to a wider social and academic support network, in a relaxed and informal environment, that comprises their peers and tutors as well as first-year lecturers and other senior academic staff in their programmes. This is in line with Tinto's (1993:147) argument that institutions should work towards forging personal bonds among and between students, faculty and staff if they aim to improve student retention.

\section{Methods}

This study used a generic qualitative design (Merriam 1998), while drawing on elements associated with longitudinal research (Ruspini 2002; Saldana 2003). A generic qualitative research design allowed us the flexibility to use a number of qualitative data collection and analysis tools to describe, interpret and understand the experiences of participants. The following question guided our deliberations in this study: How do student teachers describe the role of an education excursion as catalyst for their social integration into university and how do they reflect on their experiences thereof 30 months later?

Data were generated in two phases. In phase one, data came from two groups of students $(n=227)$, in 2014, in the first few weeks of their university studies. We used an open-ended biographical questionnaire to gather background information on students' home languages, their family life and selfreported socio-economic status and living circumstances. Students then attended the three-day excursion. Thereafter, once they had returned from the excursion, students completed a qualitative questionnaire, of which a number of items targeted elements related to social integration. Questions focused, for instance, on how they made friends on campus and with whom. Here we specifically asked students to identify the strategies and excursion activities that had the most impact on their ability to integrate socially. Data from the questionnaires were captured on Excel spreadsheets, in intact student cohort groups with separate tabs for the responses to each question. As students were asked to provide their student numbers, it was relatively simple to keep track of students over time, for example which students had persisted up to third year.

Phase two data collection was half way through the students' third year, in 2016. Here dyadic interviews with a sample of students were conducted as follow-up. Dyadic interviews allowed two participants to interact with the interviewer in response to open-ended questions (Morgan et al. 2013). Thus, we could elicit participants' responses to the nature of their social integration and ascertain which friendships had persisted over time in a safer zone that we would have been able to do with a larger focus group. These interviews were conducted by the second author and transcribed verbatim for analysis. 
Qualitative content analysis was used to make sense of the various data sets. The transcribed data were analysed separately by both authors, using a form of open coding (Charmaz 2003; Henning, Van Rensburg \& Smit 2004; Merriam 1998), before we compared key issues. Where there were differences, the data were scrutinised together by the two authors in order to get consensus. Thereafter, the separate findings were consolidated to form the outcomes of this research.

\section{Ethical considerations}

Ethics approval was granted by the Faculty of Education's Ethics Committee (2013-060) and pseudonyms were allocated to participants to protect their identity.

\section{Findings}

The first-year student data shows how the excursion environment has been beneficial in helping them traverse their individual differences and find shared or common ground as a basis for social integration. It also provides evidence that the social, playful tone of the excursion activities promotes social interaction and helps students address their fear of English. The interview data, collected more than 2 years later, where students vividly recall specific activities and incidences that helped create social cohesion, provide some evidence of the enduring influence of the excursion. There is also some evidence in the sample interviewed that the excursion has contributed to students' academic success or persistence at university. In reporting on the findings, we make reference to the racial groupings 'black', 'mixed race', 'Indian' and 'white' which is reflective of the four major race divisions under apartheid which are still frequently used. Table 1 provides a synopsis of key data from the student survey, which is relevant for the findings presented.

\section{Finding points of commonality despite differences in race, culture and religion}

One of the main issues that came up in the student responses was that the excursion created an icebreaker of sorts for students to begin integrating socially. From Table 1, it is evident that most students either did not know anyone in

TABLE 1: Extracts of student responses from questionnaire data.

\begin{tabular}{lcc}
\hline Item in questionnaire & $\begin{array}{c}\text { Intermediate phase } \\
\text { students (Grades } \\
\mathbf{4 - 7})(\boldsymbol{n}=\mathbf{1 2 2})\end{array}$ & $\begin{array}{c}\text { Foundation phase } \\
\text { students (Grades } \\
\mathbf{R - 3})(\boldsymbol{n}=\mathbf{1 0 5})\end{array}$ \\
\hline $\begin{array}{l}\text { Number of students who did not know } \\
\text { anyone in their first-year group or class }\end{array}$ & 98 & 84 \\
$\begin{array}{l}\text { Number of students who report feeling } \\
\text { a little or very scared that they would } \\
\text { not fit in }\end{array}$ & 104 & 38 \\
$\begin{array}{l}\text { Number of students who report not } \\
\text { having had any close contact with } \\
\text { students from different cultural, racial } \\
\text { and language groups }\end{array}$ & 116 & 98 \\
$\begin{array}{l}\text { Number of students reporting that } \\
\text { excursion and group work at the excursion } \\
\text { assisted most with social integration }\end{array}$ & 107 & 89 \\
\hline
\end{tabular}

their first-year group by the 5th week of class or were a little scared that they would not fit in; the excursion provided a chance for these to be addressed. From the data in Table 1, it seems that despite having grown up in a democratic, nonracial society, many of the students had in fact had very few opportunities to mix in educational or social settings with other racial or cultural groups. Thus, given the general composition of a first-year class at a Johannesburg university, the excursion provided opportunities for students to change this. For black students in particular, who are in the majority in each cohort, this was often a first social encounter with someone from a different race group as evidenced by the following:

'It made me mix with different races and language groups because my friends here in Soweto are all black. I had to mix with indians and coloureds. And, I learned to share a table with whites'. (Black Foundation Phase student, female)

'I never thought in my life I would have conversation with indians and coloureds. It made me realise that we are the same; just the colour that separates us. It helped me a lot because it was my first time having a proper conversation with other races and female genders'. (Black Intermediate Phase student, male)

'We used to see whites when we go to town in Pretoria [a city in South Africa]. We were not exposed to seeing other people from different racial groups except indians. So, it was a big deal for us to see a white person in our class. To us having a white friend was an achievement'. (Black Foundation Phase student, Female)

For the Indian students, mixed race students and white students, the response was similar - for many it was the first time they would interact closely with black people. Prior to the excursion, such interactions were often limited by the subservient positions black people held in students' homes or family businesses or simply as passers-by:

'I think the most exposure I had was with the domestic worker [usually an older African woman] or when I would go with my dad to the shop and customers would come into his shop and then I would engage with the customers. But, it was very minimal engagement with people from different races'. (Indian Foundation Phase student, female)

The nature of the excursion environment, where students lived in small group-dormitories, with shared eating and ablution facilities, and where they had ample time for leisure activities at the swimming pools, nature walks and fireside chats, provided multiple opportunities for informal student engagement. Based on the qualitative data, the excursion setting created opportunities for students to learn to get to know the other (Butin 2003; Petersen 2007) thus de-emphasising differences and understanding points of commonality:

'I always thought that only black people were poor and have a hard life but after spending time with other races, it made me realise that we go through the same difficulties'. (Black Foundation Phase student, male)

'I never thought other races struggle with money like us blacks until I heard the stories from the girls we talked to. We are alike 
in most things. ... I understood that even though we are different races and cultures we still experience the same issues'. (Black Intermediate Phase student, female)

It also appears as if the close living environment created the space for students to begin to establish relationships and share personal stories with each other:

In the rooms where we slept, we shared lots of personal experiences and I realised that I'm not alone'. (Black Foundation Phase student, female)

The excursion also created the conditions in which students could explore their racial and cultural differences and learn about the other in a safe environment:

'There was no other way I would have known about other people's cultures if we were not together at the excursion'. (Indian Foundation Phase student, female)

'I always spoke to Zulu people but there [at excursion] I spoke to Sotho and Xhosa as well. Where I come from there is only Zulu people so I didn't know anything about other people'. (Black Foundation Phase student, male)

'I never thought I will make friends with Venda and Zulu people'. (Sotho speaking, Intermediate Phase student)

Exploring religious difference also became possible. For instance, many African students had not interacted with Muslim people before and were unclear about the reasons for their special diet and, for instance, why the female students wore headscarves or long garments that covered their bodies. Likewise, for the female Muslim students, especially those who had grown up in very conservative environments, mixing with other races and genders was disconcerting at first. The structured discussion forums and informal learning groups created space for students to explore their questions about different religions:

'I always thought Muslim values are different from other cultures but I learned that we are all the same'. (Black Intermediate Phase student, female)

'Because I am Muslim, the school that I went to only had Muslim girls, so I wasn't used to interacting with people from different races and cultures. Coming to university, I didn't know anyone and I was afraid to approach people. So, it was quite a challenge making friends in the first two weeks. In my culture and religion, we wouldn't normally engage with the opposite sex or a different gender, so I was even more afraid'. (Indian Foundation Phase student, female)

'I used to think that Rasta people's lives focus on not eating meat and smoking weed but after meeting and talking to a Rasta student I wouldn't mind to mix myself with them'. (Black Foundation Phase student, male)

\section{Addressing the fear of using English as a language of communication}

One of the biggest impediments to students' social interaction in the first year seems to be the difficulties the majority of them face with English as the primary language of communication and academic work. This is an enduring problem in South Africa, which many researchers argue stems from the policy of home language instruction (in one of 11 official languages in different parts of the country) up to the end of Grade 3 with a switch to English as the main language of teaching and learning in Grade 4 . The difficulties of this have been widely documented in South African research literature (Pretorius \& Spaull 2016) as has its negative effects on school children's educational outcomes further up the education chain (Pretorius \& Spaull 2016). In addition, many black students in particular may come from impoverished education backgrounds, with limited access to books and libraries (Jackson 2000) and teachers who are not fluent English speakers. These students then face tremendous struggles with English when they enter university, where it is the main language of communication and of teaching and learning. The majority of students spoke at length of their struggles with English as evidenced by the following:

'I think I struggled 'cos I am from a community where there are only blacks ... so being exposed to sitting next to a white person or an indian person is something else because you get worried about your speech. You don't know how to put things ... you don't know how to express yourself in the English language because we were taught in our home language and we did not speak English'. (Black, female, Foundation Phase student)

'So for me coming from a background which I did not speak English is a problem in my first-year. It even lowered my esteem because I'd go from campus to home without talking to anyone because of the language barrier'. (Black Intermediate Phase student, male)

'I'm from Polokwane from Laboya. Then English wasn't my thing, I found out like people at here varsity speak like ... fluent. I was so scared to, to, to introduce myself to them. I was so scared that I would make mistakes and they would laugh at me. I speak broken English ... everyone will end up laughing at me... I don't want others to hear that ay my English is broken, is horrible. ... It was so difficult ... language'. (Black, Intermediate Phase student, female)

The logistics of the excursion, small rooms accommodating 12 students and placing students in small working groups of 10 for curriculum activities seems to have helped students get over some of their discomfort with expressing themselves in English. Based on the evidence in the data, we surmise that it may be the safety of the small group that encouraged this:

'Because I was always afraid to talk when am around whites and coloureds, lucky I was sharing a room with those races and I am now able to talk to them'. (Black Intermediate Phase student, male).

'From people like her (person A) that I shared a room with at the camp, we got to talk more English, because I was not exposed to it that much at school'. (Black, Foundation Phase student, female)

\section{The relaxed social tone of the games and activities promotes interaction}

It looks as if the organisers' deliberate subdivision of students into small multiracial and multilingual working groups as 
well as the range of games, simulations and group-based activities provide many opportunities for students to engage. The interactive nature of the simulation games and the topical issues they address such as HIV, AIDS and food security and the emphasis on music and team building activities are what are remembered by students, both in the survey data collected after the excursion and from the interview data 3 years later:

'I feel the excursion was like a team building kind of exercise, because it allowed us to get out of our comfort zones and the activities we had. We were obligated to make new friendships, because some activities required group work ... interaction. So, the excursion taught us to make new friends. At the end of the day me and person $B$ met when we were in the same group in the excursion. So from then on we grew to be so close, like brothers in a way'. (Black Foundation Phase student, male)

'When we did the HIV and AIDS game. ... When I had to say to other students, "can I have this nice time with you" and then we would laugh and laugh. You would go to any person around ... you would ask to pour the mixture into that person's cup. ${ }^{1}$ So it really made us talk to each other. ... It broke down barriers ... you would have to talk to the person'. (Black Foundation Phase student, male)

'The drumming ... it was an exciting opportunity where you were beating your own drum but you were laughing and doing things together with other people. At times you would take to the floor to dance there with people of different races, people that we have never spoken to before. So again the excursion brought us together as a class to interact with each other, because we were able to go there dance freely'. (White Intermediate Phase student, female)

'The play performances using recyclable materials ... the dancing and the making clothes ... that was very interesting because we talked about the materials we used and we laughed at each other. We were not even aware of each other's creativity. We developed friendships from there because afterwards we knew this person likes this ... your dress in a way told a story about you'. (Black Foundation Phase student, female)

The relaxed informal environment also allowed students to see their lecturers in a different light.

'When we went for the excursion ... I also had the opportunity to interact with the lecturers apart from interacting only with the students. So, this has really helped me to cope with the university life here at UJ'. (Black Foundation Phase student, male)

\section{Excursion environment as catalyst for enduring social integration}

More than two and a half years later, students still recount the role of the excursion as a catalyst for promoting social integration. This is pertinently captured in the following vignette from an international black student who described his distress in the first few weeks of university and how this was turned around by the excursion experience. His descriptions of his social exclusion and isolation should be read against the background of frequent, and often violent, xenophobic attacks on foreign nationals from other parts of Africa, from South Africans (much of this has to do with competition for scarce resources among the poorest of the poor in the country):

'If I could have a single story to tell about my life at the university, then I will start talking about the excursion, because all the challenges I had in the first few weeks of university were still there until we went for the excursion. No one greeted me or spoke to me. They would not even shake hands with me. I would like just to say that life at university the very first few days was really very hard'. (Black foreign student, male)

'Now what happened at the excursion? After a session, ... I would see four or five students coming to ask me ... what's your name? Where you from? You see, I came now to start talking to different people. So, that was like the trend until we finished the three days. After every session, people would come ask a few questions, interested to know much about me. I had a number of conversations with people that I was not even talking to here at varsity. It's amazing that today we (person $\mathrm{X}$ and $\mathrm{Y}$ ) and I are friends ... this friendship started at the excursion, that's where they started talking to me ...' (Black foreign student, male)

In 2017, this student is now a respected senior tutor in his fourth year, who, as a top achiever, assists junior students with academic support and has become spokesperson for his class group. He also accompanies staff each year on the firstyear excursion and acts in the capacity of peer mentor to new students.

Other students give similar reports of how friendships started at the excursion have persisted over 3 years of study:

'Our relationship started at the excursion and is still growing. I made friends with Soraya [an indian Muslim student] right at the excursion. She was one such a person that we, previously could not "see" before we went for the excursion. She is now the one that I am working with, either as a tutor, or if there is class work that I don't understand. Or, if there is work she doesn't understand, we are able to approach each other. Or, we just make time to chat. This relationship started at the excursion'. (Black Foundation Phase student, male)

I have a friend, whom I met at the excursion. We were in the same class. Then at the excursion we shared the same room. We starting chatting ... so, after the excursion ... I came back and made some changes to my attitude and work and I ended up seeing myself as a real student, not the same one that came to the university. I still have those friends. (Black Foundation Phase student, female)

From the excursion, I made a lot of friends and we are still friends now. I met those guys, because we shared a room. We played chess ... one of them told me he is a soccer player ... I was also a soccer player ... now we play for the same team. We are still friends. (Black Intermediate Phase student, male)

\section{Discussion of findings}

First years, as newcomers in a university academic community, have to find mechanisms for fitting in and establishing connections with their peers, classmates and lecturers. From the data in this study, it is evident that South African students like their counterparts in the rest of the world, struggle with 
issues of belonging, settling into university and making friends. In addition, the students, despite growing up in a democratic society, still seem affected by the legacy of their racially divided history. The first-year pre-excursion data in this study provide evidence of students' struggles with traversing their racial, cultural, language and religious differences. We are of the view that unless deliberate opportunities are created for this to occur early in their entry to university, they are not likely to throw off the yolk of their habitual racial, cultural and/or language groupings. The excursion as intervention seems to have been successful in creating the conditions under which students would be able to confront and address their stereotypes, preconceptions and fears about the other in a safe space (De Beer \& Henning 2011). Both the excursion setting and its suite of activities provide opportunities for students to come to know their classmates, oftentimes classmates with whom they would not interact under normal university classroom conditions. It also provides opportunities for students to initiate new friendships and relationships, both for the purposes of establishing a group of friendly peers and also as a means of creating a peer support group to assist with academic work back at the university.

We also believe the excursion has been most beneficial in disrupting students' fear of not fitting in so that they begin to perceive a good fit between their needs and interests, and those of the institution, making them more likely to persist in their studies (Tinto 1993). From the data, there is evidence that the excursion has helped in easing the feeling of despair, loneliness and confusion during students' initial entry to university. In earlier research, De Beer and Henning (2011) contend that even students who have been isolated until the excursion are given ample opportunities to establish bonds with a significant other individual or community. When students are able to transfer the informal social learning networks from the excursion to the formal university classroom environment, then the feeling of 'not belonging' diminishes.

In particular, the informal, often playful social tone of the excursion activities also contributes to a more relaxed learning atmosphere and helps bridge the gap between university lecturers and the students (De Beer \& Henning 2011). At the excursion, away from the formality of lecturerstudent interactions in the university environment, students can see their lecturers in a different light and engage differently in interaction with each other. The informal games, comfortable talks around the campfire and shared mealtimes encourage students' to forge a different kind of relationship with the university faculty staff, which is likely to support students' commitment to their studies (Pitkethly \& Prosser 2001). It also positively influences students' knowledge and awareness of the diverse spectrum of other students and peers within the university (Pitkethly \& Prosser 2001). In our view, these are vital for promoting retention.

Lastly, we are encouraged by student reports of the value of the excursion for the development of a friendly peer group who can assist with integration and where necessary for academic assistance. As Bojuwoye (2002) argues, early identification of the difficulties of first-year students' is vital for intervention strategies and for encouraging student integration in the new university environment. For students, such as those in this study, who come from impoverished educational backgrounds, with limited access to books and libraries, and poor English language skills the university can be particularly alienating (Ivanič 1998). If such students do not find mechanisms to become acquainted with the dominant modes and literacy practices of the university, they may be hampered in their knowledge-making resulting in restricted 'epistemological access' (Morrow 2007:41). In our view, the excursion provides opportunities for students to begin crafting informal learning communities, which is invaluable for helping them fit in and make sense of the pedagogical, linguistic and rhetorical conventions of their areas of study.

Evidence of the students' recognition of the value of the excursion over time is evident in the numerous requests by senior students to accompany first years on subsequent excursions (Govender 2014). A number of senior students, who are employed as academic tutors, accompany staff and take charge of the student interactions and group work, assist lecturers and help facilitate the sessions. They are also available as a senior peer that students can relate to more easily than the lecturers. This relationship of support then also continues on the university campus, as student tutors are readily available in weekly timeslots for first-year academic and social support.

\section{Conclusion}

Barefoot et al. (1999) stress that universities should ensure that FYE programmes are larger than a single seminar course and represent a planned and comprehensive programme. The FYE programme should thus consist of different components working together to increase academic performance and constitute a far-reaching learning experience so as to increase student persistence. The ideal programme should also assist students in the transition to university, facilitate a sense of commitment and community to the university and increase the personal development of students. Creighton (2007) argues that the earlier the identification of the academic and adjustment difficulties that first-year students experience, the better the opportunities for intervention and student integration in the new university environment. In this study, both the qualitative survey data and the interview data, generated two and a half years later, in which students look back on the role of the excursion, point to its influence as a catalyst for their social integration. We thus feel relatively confident in claiming that the education excursion at the UJ does indeed serve as a socially cohesive device for students and provides a practical contribution for student enculturation to the field of FYE programmes.

\section{Acknowledgements}

This project formed part of a National Research Foundation Thuthuka Project (grant holder: Nadine Petersen). 


\section{Competing interests}

The authors declare that they have no financial or personal relationships which may have inappropriately influenced them in writing this article.

\section{Authors' contributions}

N.F.P. and D.A. conceptualised the article jointly. D.A. was responsible for data generation and both N.F.P. and D.A. analysed the data. N.P. drafted the first iteration of the manuscript. D.A. took care of technical editing. In essence, both authors worked together to complete the manuscript submitted for consideration in the journal.

\section{References}

Academic Development and Support Annual Report, 2015, Overview of the academic development and support domain, The University of Johannesburg, viewed 14 March 2017, from https://www.uj.ac.za/corporateservices/ads/Documents/ Academic $\% 20$ Development $\% 20$ and $\% 20$ Support $\% 20$ Annual $\% 20$ Report $\% 20$ 2015.pdf

Barefoot, B.O., Fidler, D.S., Gardner, J.N., Moore, P.S. \& Roberts, M.R., 1999, 'A natural linkage: The first year seminar and the learning community', in J.H. Levine (ed.) Learning communities: New structures, new partnerships for learning (Monograph No. 26), National Resource Center for the First Year Experience \& Students in Transition, University of South Carolina, Columbia, SC.

Berkovitz, R.A. \& O'Quinn, K., 2006, 'Predictors of graduation of readmitted "at-risk" college students', Journal of College Student Retention 8(2), 199-214. https://doi. org/10.2190/876B-JF9P-RGFU-9XD6

Bojuwoye, O., 2002, 'Stressful experiences of first year students of selected universities in South Africa', Counselling Psychology Quarterly 15(3), 277-290. https://doi.org/10.1080/09515070210143480

Braxton, J.M. \& McClendon, S.A., 2001-2002, 'The fostering of social integration through institutional practice', Journal of College Student Retention: Research, Theory and Practice 3(1), 57-71. https://doi.org/10.2190/RGXJ-U08C-06VB-JK7D

Butin, D.W., 2003, 'Of what use is it? Multiple conceptions of service-learning within education', Teacher Education 105, 1674-1692.

Cavote, S. \& Kopera-Fryke, K., 2007, 'Non-traditional student persistence and first yea experience courses', Journal of College Student Retention 8(4) 477-489. University of Nevada, Reno.

Charmaz, K., 2003, 'Qualitative interviewing and grounded theory analysis', in J.A. Holstein \& J.F. Gubrium (eds.), Inside interviewing: New lenses, new concerns, pp. 311-330, Sage, London.

Council on Higher Education, 2010, Access and throughput in South African higher education: Three case studies, Higher Education Monitor No. 9', viewed 04 education: Three case studies, Higher Education Monitor No. 9', viewed 04
July 2014, from http://www.che.ac.za/sites/default/files/publications/Higher_ July 2014, from http://WW
Education_Monitor_9.pdf

Council for Higher Education, 2013, A proposal for undergraduate curriculum reform in South Africa: A case for a flexible curriculum structure, Report of the Task Team on undergraduate curriculum structure, CHE, Pretoria.

Creighton, L.M., 2007, 'Factors affecting the graduation rates of university students from underrepresented populations', Journal of College Student Retention: Research, Theory, \& Practice 5(4), 409-420.

DeBerard, M.S., Spielmans, G.I. \& Julka, D.C., 2004, 'Predictors of academic achievement and retention among college freshman: A longitudinal study', College Student Journal 38(1), 66-80.

De Beer, J. \& Henning, E., 2011, 'Retreating to a Vygotskian stage where pre-service teachers play out social, 'dramatical collisions', Acta Academica 43(4), 203-228.

De Beer, J., Petersen, N. \& Dunbar-Krige, H., 2012, 'An exploration of the value of an educational excursion for pre-service teachers', Journal of Curriculum Studies 44(1), 89-110.

Du Preez, R., Steenkamp, L.P. \& Baard, R.S., 2013, 'An investigation into a peer module mentoring programme in economic and management sciences', The International Business \& Economics Research Journal 12(10), 1225. https://doi.org/10.19030/ iber.v12i10.8133

Fan, M., Buckley, R. \& Litchfield, R.C., 2012, 'Orientation programs that may facilitate newcomer adjustment', Research in Personnel and Human Resources Management 31, 87-143.

Govender, S., 2014, 'Tutors' roles in the formation of learning communities during an educational', Master's thesis, Department of Education, University of Johannesburg.

Henning, E., Van Rensburg, W. \& Smit, B., 2004, Finding your way in qualitative research, Van Schaik Publishers, Pretoria.

Hunter, M.D., 2006, 'Fostering student learning and success through first-yea programs', Association of American Colleges and Universities 8(3), 4-8.

Ivanič, R., 1998, Writing and identity: The discoursal construction of identity in academic writing, John Benjamins, Amsterdam.
Jackson, M., 2000, Students' learning needs in an English language foundation course, viewed 21 April 2001, from World Wide Web http://www.ru.ac.3/academic/adc/ papers/jackson/html

Jenkins-Guarnieri, M.A., Horne, M.M., Wallis, A.L., Rings, J.A. \& Vaughn, A.L., 2015, 'Quantitative evaluation of a first-year seminar program: Relationships to persistence and academic success', Journal of College Student Retention 16(4), 593-606. https://doi.org/10.2190/CS.16.4.f

Kuh, G.D., 2003, 'What we're learning about student engagement from NSSE', Change 35(2), 24-32. https://doi.org/10.1080/00091380309604090

Leibowitz, B., Van der Merwe, A. \& Van Schalkwyk, S., 2012, Focus on first-year success: Perspectives emerging from South Africa and beyond, revised edn., SUN MeDIA, Stellenbosch.

Letseka, M. \& Maile, S., 2008, High university drop-out rates: A threat to South Africa's future, viewed 08 July 2014, from http://www.hsrc.ac.za/uploads/pageContent/ 1088/Dropout\%20rates.pdf

Mayo, D., Helms, M. \& Codjoe, H., 2004, 'Reasons to remain in college: A comparison of high school and college students', International Journal of Educational Management 18(6), 360-367. https://doi.org/10.1108/09513540410554013

Merriam, S.B., 1998, Qualitative research and case study applications in education. Revised and expanded from case study research in education, Jossey-Bass, San Francisco, CA.

Miller, J.W. \& Lesik, S.S., 2014, 'College persistence over time and participation in a first-year seminar', Journal of College Student Retention: Research, Theory \& Practice 16(3), 373-390. https://doi.org/10.2190/CS.16.3.d

Moja, T., 2010, Diversity orientated transformation for teaching and learning, Public Lecture at the University of Johannesburg, viewed 12 August 2010, from http:// www.ngopulse.org/event/public-lecture-diversity-oriented-transformation teaching-and-learning

Monama, T., 2013, 'University dropouts outnumber graduates', Timeslive, viewed 14 July 2014, from http://www.timeslive.co.za/thetimes/2013/08/22/universitydropouts-outnumber-graduates

Moodley, P. \& Singh, R.J., 2015, 'Addressing student dropout rates at South African universities', Alternation Special Edition 17, 91-115.

Morgan, D.L., Ataie, J., Carder, P. \& Hoffman, K., 2013, 'Introducing dyadic interviews as a method for collecting qualitative data', Qualitative Health Research 23(9), 1276-1284. https://doi.org/10.1177/1049732313501889

Morrow, W., 1994, 'Entitlement and achievement in education', Studies in Philosophy and Education 13(1), 33-47. https://doi.org/10.1007/BF01074084

Morrow, W., 2007, Learning to teach in South Africa, HSRC Press, Pretoria, p. 41.

Murray, M., 2014, 'Factors affecting graduation and student dropout rates at the University of KwaZulu-Natal', South Africa Journal of Science 110(11/12), 1-6. https://doi.org/10.1590/sajs.2014/20140008

Pace, C.R., 1980, 'Measuring the quality of student effort', Current Issues in Higher Education 2, 10-16.

Palmer, P., 1998, The courage to teach: Exploring the inner landscape of a teacher's life, Jossey-Bass, San Francisco, CA.

Petersen, N., 2007, 'Pre-service teacher education students' engagement with care and social justice in a service learning module', Education as Change 11(3), 169-181. https://doi.org/10.1080/19479417.2007.11673773

Petersen, N., 2014, 'Childhood education student teachers responses to a simulation game on food security', South African Journal of Childhood Education 4(1), 1-16. game on food security', South African Jour
https://doi.org/10.4102/sajce.v4i1.115

Petersen, N., De Beer, J. \& Dunbar-Krige, H., 2011, 'Use of a simulation game for HIV/ AIDS education with pre-service teachers', African Journal of AIDS Research 10(1), 73-81. https://doi.org/10.2989/16085906.2011.575550

Pitkethly, A. \& Prosser, M., 2001, 'The first year experience project: A model for University-wide change', Higher Education Research \& Development 20, 185-198. https://doi.org/10.1080/758483470

Pretorius, E.J. \& Spaull, N., 2016, 'Exploring relationships between oral reading fluency and reading comprehension amongst English second language readers in South Africa', Reading and Writing 29, 1449-1471. https://doi.org/10.1007/s11145 016-9645-9

Quinn, J., 2013, Drop-out and completion in higher education in Europe, viewed 20 July 2014, from http://www.nesetweb.eu/sites/default/files/HE\%20Drop $\% 20$ July 2014, from http://W
out $\% 20 A R \% 20$ Final.pdf

Ruspini, E., 2002, Introduction to longitudinal research, Routledge, London.

Saldana, J., 2003, Longitudinal qualitative research, Alta Mira Pres, New York.

Scott, I., Yeld, N. \& Henry, J., 2007, 'A case for improving teaching and learning in South African higher education', Higher Education Monitor 6, 1-86.

Seligman, J. \& Gravett, S., 2010, 'Literacy development as "a marginalised pedagogical service enterprise" or as a social practice in the disciplines', Education as Change 14(1), 107-120. https://doi.org/10.1080/16823206.2010.494340

Smith, B.L., 2001, 'The challenge of learning communities as a growing national movement', AAC\&U Peer Review 4(1), 4-8.

Smith, D., 2013, 'South Africa's universities "racially skewed," claims watchdog', The Guardian 22 August, 2013, viewed 19 July 2014, from http://www.theguardian. com/global-development/2013/aug/22/south-africa-universities-racially-skewed

Teaching and Learning Report, 2016, Achieving excellence in teaching and learning, The University of Johannesburg, viewed 03 October 2018, from https://www.uj. ac.za/about/Reports/2016\%20U__Teaching\%20and\%20Learning.pdf

Tinto, V., 1975, 'Dropout from higher education: A theoretical synthesis of recent research', Review of Educational Research 45, 89-125. https://doi.org/10.3102/ 00346543045001089 
Tinto, V., 1987, 'The principles of effective retention', Fall conference of the Maryland College Personnel Association, viewed 20 November 1987, from http//www.eric. ed.gov/ERICWebPortal/custom/portiets/recordDetails/detailmini.jsp

Tinto, V., 1993, Leaving college: Rethinking the causes and cures of student attrition 2nd edn., University of Chicago press, Chicago, IL, p. 147.

Turner, V., 1969, The ritual process: Structure and antistructure, Aldine De Gruyter, New York.

Van Gennep, A., 1969, The rites of passage, transl. M.B. Vizedom \& G.L. Caffee, University of Chicago Press, Chicago, IL.
Van Zyl, A., 2010, 'The predictive value of pre-entry attributes for student academic performance in the South African context', PhD thesis, University of Johannesburg, p. 35.

Van Zyl, A., Gravett, S. \& De Bruin, G.P., 2012, 'The predictive value of pre-entry attributes for student academic performance in the South African context', South African Journal of Higher Education 26(5), 1095-1111. https://doi.org/10.20853/ 26-5-210

Zhao, C. \& Kuh, G.D., 2004, 'Adding value: Learning communities and student engagement', Research in Higher Education 45(2), 115-139. https://doi.org/ 10.1023/B:RIHE.0000015692.88534.de 